\title{
Regrassing flood-damaged pastures
}

\author{
Institute of Natural Resources, Massey University, PB 11222, Palmerston North \\ mwilson@lic.co.nz
}

\begin{abstract}
On the night of February 14th 2004 the lower North Island was hit with a storm system, which would cause the biggest flood seen in the region for over 100 years. The hardest hit areas include the Manawatu, Rangitikei, Horowhenua, Wairarapa and Wanganui regions. In the summer after the event, a survey was conducted of the affected areas. Semi-structured interviews of 52 individual farmers focused on their farm operations, the impact of the flood, and their regrassing strategies. The interviews established the state of the pastures postflood including depth and texture of silt deposit; water levels and flow; duration of inundation; and soil surface condition. The regrassing strategies included seedbed preparation, sowing technique, fertilizer use and weed control. Site measurements made were: pasture cover and species content, and that soil profiles revealed rooting depth and silt depth (if not cultivated). General trends that emerged were that the more thoroughly a seedbed was prepared the lower the risk of pasture establishment failure. Nitrogen (N) applications of 75 $\mathrm{kg} / \mathrm{ha}$ over the intervening period did not have a significant effect but where deep sediment was encountered two or three applications of $\mathrm{N}$ was reported to produce feed and start inputting organic matter $(\mathrm{OM})$. The use of a roller drill increased the reliability of establishment and was essential for the establishment of pasture legumes. Double normal seeding rates (30-40 $\mathrm{kg} / \mathrm{ha}$ ) increased the reliability of success where the seed was broadcast. Many farmers that had no sediment reported perennial weed problems including couch, creeping buttercup and a variety of thistles. Small scale surface cultivation was reported to decrease drying time dramatically in extremely wet areas.
\end{abstract}

Keywords: ground cover, pasture cultivars, pasture establishment, seedbed preparation, weeds and pests

\section{Introduction}

From time to time, farmers are exposed to extreme environmental perturbations. The Agriculture and Resource Management Council of Australia and New Zealand describe these 'exceptional circumstances' as one in 20 to 25 year events (ARMCANZ 1999). In February 2004 flood the lower North Island was hit with three storms in relatively quick succession. The first caused the biggest flood seen in the region since 1902. Highest peak flows since recording began were recorded on the Whanganui and Whangaehu rivers and third highest on the Rangitikei and Manawatu rivers (NIWA 2005). Over a 36-hour period, $180 \mathrm{~mm}$ of rain fell. The heaviest falls occured in on the Tararua and Ruahine Ranges and on the southern slopes of Mt Ruapehu that fed the upper catchments of the rivers. The hardest hit areas included the Manawatu, Rangitikei, Horowhenua, Wairarapa and Wanganui regions. It was estimated that approximately 20000 ha was inundated for a period long enough to destroy pastures and crops (Andrew Steffert, Horizons Regional Council, pers. comm.).

A summary of soil tests conducted on the sediments (Litherland 2004) indicate that most of the silt deposited was reworked mudstone with low phosphorus (P) retention $(<30 \%$ anion storage capacity (ASC)). They were marine in origin and had a neutral to slightly alkaline reaction ( $\mathrm{pH}$ 6.6-7.7). The low OM (0.6-1.7\%) and available $\mathrm{N}(13-68 \mathrm{~kg} / \mathrm{ha})$ indicated little topsoil in the material. Further west in the Whangaehu catchment the sediment had a moderate P retention (34-42\% ASC) and OM (2.8\%) implying that these sediments were derived from tephric soils.

While little can be done to lessen the impact of these events there is much that can be done to speed recovery. The 2004 February floods in the Manawatu was such an event and presented an opportunity to gather the experience of the many farmers, farm advisors, and company representatives who were involved in the restoration of pastures. In an unmanaged perturbation, such as a flood, there are many variables that can affect recovery strategies. A review of the literature indicated that there was little published information on the recommended course for recovery from floods on farms (Litherland 2004). The wide range of circumstances and variable success rates of regrassing pasture presented an opportunity to review strategies taken by farmers. This paper reviews the success rate of various strategies in the summer after the event.

\section{Methods}

Affected farmers were selected from a short-list provided by Federated Farmers from the Oroua, Pohangina, Manawatu, Rangitikei and Whangaehu catchments. Further contacts were made by 'snowball' sampling (Patton 1990) where interviewed farmers recommended further contacts. Thus the cases were not randomly selected and it is possible that groups of farmers in different networks were excluded. The farmers were well 
Table 1 The effect of seedbed preparation, sowing method and $\mathrm{N}$ application on the pasture cover, expressed as the percentage frequency of cases reaching a given ground cover.

\begin{tabular}{|c|c|c|c|c|}
\hline & \multicolumn{4}{|c|}{ Ground cover (\%) } \\
\hline & $<25$ & $26-50$ & $51-75$ & $>75$ \\
\hline \multicolumn{5}{|c|}{ — $\%$ of cases } \\
\hline Minimal & 10 & 20 & 29 & 42 \\
\hline Full & 3 & 7 & 29 & 61 \\
\hline \multicolumn{5}{|l|}{ Sowing method } \\
\hline Broadcast & 13 & 18 & 30 & 38 \\
\hline Direct drilled & 1 & 21 & 37 & 41 \\
\hline Roller drilled & 2 & 6 & 19 & 74 \\
\hline \multicolumn{5}{|l|}{$\begin{array}{l}\mathrm{N} \text { application } \\
\text { (kg/ha/yr) }\end{array}$} \\
\hline Nil & 10 & 13 & 28 & 48 \\
\hline $10-35$ & 3 & 21 & 24 & 52 \\
\hline $36-75$ & 0 & 13 & 38 & 50 \\
\hline$>75$ & 7 & 10 & 28 & 55 \\
\hline
\end{tabular}

distributed geographically except for the Rangitikei flood plain where only one farmer was contacted. The interviews were conducted in November and December 2004, and January 2005.

The interviews were semi-structured focusing on their farm operations, the impact and duration of the flood, and their regrassing strategies. On many farms more than one scenario was described and these were treated as individual cases. The interviews established the state of the pastures immediately post-flood including: depth and texture of silt deposit; water levels and flow; duration of inundation; and soil surface condition. The regrassing strategies included: seed bed preparation, sowing technique, quantity and frequency of fertiliser use, and weed control. Fifty-two farmers were interviewed and this resulted in 110 'cases' being described.

For each case a site inspection was made. An estimate of ground cover was made on two $30 \times 30 \mathrm{~cm}$ quadrats/ case. Pastures were clipped to a standard $8 \mathrm{~cm}$ and photographed from $1.5 \mathrm{~m}$ height vertically above the pasture. Green cover was estimated visually on quadrats using an eight-point scale of percent cover. The eightpoint scale was judged using a photographic template that had been calibrated by a pixel analysis for green/ non-g reen colour. A soil profile was exposed to record rooting depth, sediment depth if still apparent, and the presence and depth of anaerobic layers. A photograph of the soil profile was taken.

\section{Analysis}

Seedbed preparation was classified into two groupings. 'Unprepared' was untouched or a single pass of some surface implement before sowing, while 'Prepared' included some primary and secondary cultivation taking place before sowing. Nitrogen applications were grouped into 'Nil', 10-35, 36-75, and $>75 \mathrm{~kg} / \mathrm{ha} / \mathrm{yr}$. These categories split the responses into roughly equal groups. Principle Component Analysis (PCA), Regression Analysis and Pivotal Tables were used to explore trends in the data set. Hypotheses were tested using ANOVA statistical procedures.

\section{Results and discussion}

Most pastures were sown by Autumn 2004. By November 2004 only $19 \%$ of the regrassed areas had less $50 \%$ ground cover indicating that there was a serious loss of productivity. Because of the many factors involved in the re-establishing of pastures, it is difficult to identify specific 'best practices' but data presented here imply that there are some trends in the regrassing strategies.

The condition of the soil surface after the flood had receded varied. In $75 \%$ of the cases there was little ( $>5$ $\mathrm{cm}$ ) or no sediment deposited, $24 \%$ had $5-25 \mathrm{~cm}$ of sediment, and only $1 \%$ had deep sediment $(>25 \mathrm{~cm})$ on the land. Of the areas with little or no sediment, comment was made of a rotting organic layer that smelt. Even with no sediment, the flood seemed to seal the soil surface and prevent drainage. Light tillage to scratch the surface was considered by several farmers to speed the drying process. Some farmers 'mulched' the dead organic layer with favourable results.

Table 1 describes the trends that emerged from the entire database. It gives a measure of success of the regrassing strategy, where 'success' is measured by the proportion of ground cover. The major factors included the preparation of the seedbed, sowing technique and $\mathrm{N}$ application.

\section{Seedbed preparation}

A full seedbed preparation was recommended where some silt had been deposited in order to mix the new sediment into the existing soil (Anon 2004). But even 
Figure 1 The mean ground cover in spring 2004 on regrassed paddocks sown by broadcasting, direct drilling and roller drilling on unprepared and prepared seedbeds.

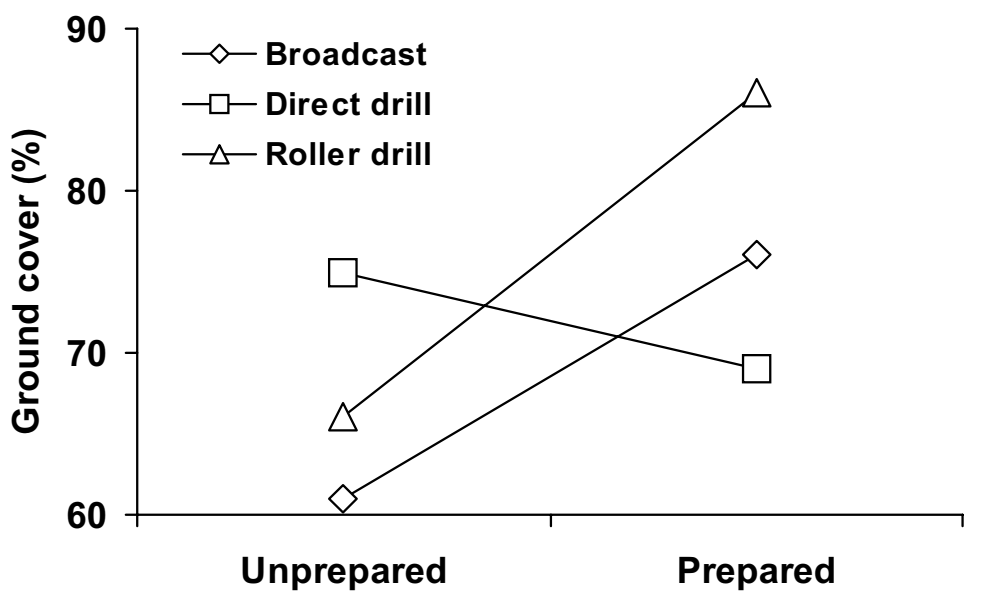

Seedbed

with no sediment pasture establishment was significantly $(\mathrm{P}=0.005)$ more reliable when some attempt was made to prepare a seedbed (Table 1).

There was a significant interaction $(\mathrm{P}=0.003)$ between the state of the seedbed and the technique used to sow the pasture (Figure 1). Broadcasting and roller drilling produced significantly higher ground cover on prepared seedbeds while direct drilling did not. Comment was made that the roller drill was particularly good for the establishment of white clover. Of the 42 cases where $50 \%$ ground cover had not been achieved, 16 were broadcast onto minimally prepared seedbeds ( 7 by helicopter) and 14 were direct drilled. There is a relatively narrow window of opportunity for broadcasting onto moist sediment (McKee \& Graham 1952; Gray \& Korte 1990); too wet and the radicle will not penetrate the anaerobic soil, too dry and the seed is blown into windrows. Also farmers that had success with broadcasting techniques attributed this success to high seed rates, usually double normal sowing rates. The poor results from direct drilling (Figure 1) seem predictable because the technology depends on good soil structure to stabilise the slot (Ritchie 1986).

\section{Nitrogen}

The application of $\mathrm{N}$ did not appear to improve establishment of the pasture (Table 1) and there were insufficient cases with deep sediment deposits to analyse.

Root depth was correlated $(\mathrm{P}<0.001)$ with ground cover (ground cover $=3.42+0.302 *$ root depth) but it explained only $21 \%\left(\mathrm{r}^{2}\right)$ of the variation. Possible causes of a shallow rooting depth included a) the coarse texture of the sediment giving a substrate with little water holding capacity, and b) very fine textured sediment with an anaerobic layers acting as a barrier. Reports w ere made of pastures with shallow root systems burning-off in summer.

The presence of anaerobic layers, produced by perched water tables, 8 to 10 months after the event implies that the old soil surface had become impermeable. A number of farmers had resorted to deep ripping to overcome this effect.

\section{Weeds and pests}

Two patterns emerged with weed and pest problems. In areas where little or no sediment was deposited, weeds presented a problem. Plants with rhizomatous, below ground storage organs survived the flood well. Couch (Elytrigia repens) and creeping buttercup (Ranunculus repens) were cited by farmers as the main weeds. Strong germination of hairy buttercup ( $R$. sardous), dock, mayweed and Poa annua were commented on. A variety of thistles also needed controlling. The consensus was that these weeds were present before the flood and flourished under the conditions. Sediment deposits were regarded as clean by most although there was a case of gorse germination in the Pohangina and lupins in the lower Manawatu. Slugs were controlled in a few cases with bait.

\section{Pasture cultivar}

McKee (1952) recommended short-rotation and Italian ryegrasses on Gisborne sediments. In this study $65 \%$ had perennial ryegrass and $25 \%$ had Italian ryegrass as the dominant component of the seed mix. There was no detectable trend in the success of pasture establishment with species/cultivar sown. The choice of species seemed to be determined more on the strategic use of the pasture 


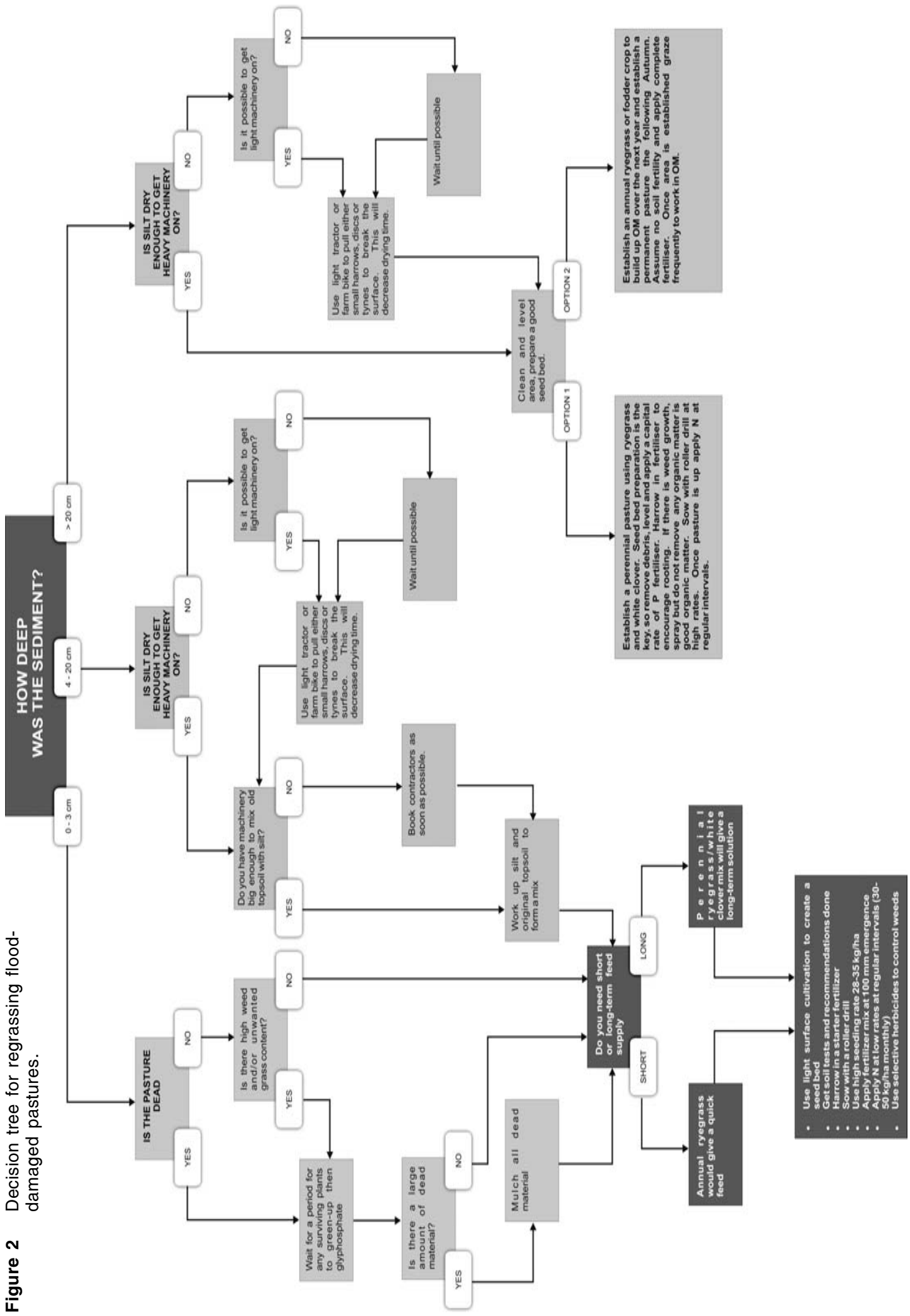


in the grazing system, rather than for their ability to colonise a hostile medium. Several farmers with deep sediment deposits had legume dominant pastures and bloat problems.

\section{Conclusions}

The advice and decision tree that was published by Anon (2004) chose four scenarios - flood sediment less than 5 $\mathrm{cm} ; 5-10 \mathrm{~cm} ; 11-25 \mathrm{~cm}$; and greater than $25 \mathrm{~cm}$. The evidence gathered here would suggest that there is little difference between the 5-10 and 11-25 cm depths and that they can be treated similar ly. Our conclusions on the best management for the three scenarios are summarised as a decision tree in Figure 2.

Where little or no silt was deposited the problem was handling the dead OM and breaking a soil surface 'seal'. Mulching the OM and light tillage was successful here. Where a modest amount of silt was deposited the solution appeared to be mixing the sediment with the existing soil profile. With deep sediment the aim was to reconstitute a soil profile. General trends that emerged with the first two scenarios were that the more thoroughly a seed bed was prepared the lower the risk of pasture establishment failure, and the greater the amount of $\mathrm{N}$ fertiliser applied, the lower the risk of failure (Table 1).

Other issues to emerge were that the use of a roller drill increased the reliability of establishment and was essential for the establishment of pasture legumes. The control of weeds after flooding must not be underestimated even though paddocks looked clean after emerging from the flood water. Perennial weeds especially survived the flooding. Several reports indicated that smallscale surface cultivation decreased drying time dramatically.

Where deep sediment was encountered high fertiliser rates to produce feed and start inputting OM seemed to be the better strategy.

This survey shows that the strategies adopted by farmers did affect the recovery of their pastures. Hence the importance of decisions trees (Figure 2) being readily available to farmers and support organisations for future floods.

\section{ACKNOWLEDGEMENTS}

Horizons Regional Council funded this work

\section{REFERENCES}

Anon 2004. Regrassing Flood Sediment. CountryWide Publications, Feilding.

ARMCANZ. 1999. Agriculture and Resource Management Council of Australia and New Zealand.

Gray, M. H.: Korte, C. J. 1990. Revegetation for river silt deposits. In: Issues in the restoration of disturbed land. (Eds PEH Gregg, RB Stewart and LD Currie). Occasional Report No. 4. Fertilizer and Lime Research Centre, Massey University, Palmerston North. pp 232-235.

Litherland, A. 2004. Regrassing silt: Technical report for professionals. AgResearch Grasslands, Palmerston North.

McKee, J.G.; Graham, G.J. 1952. Pasture establishment on flooded areas of Gisborne flats. New Zealand Journal of Agriculture 84: 197-198.

NIWA 2005. Meteor ological Hazards and the Potential Impacts of Climate Change in the ManawatuWang anui Region. NIWA Client report: WLG200517. Hamilton.

Patton, M. 1990. Qualitative Evaluation and Research Methods. Sage Publications, California, USA.

Ritchie, W.R. 1986. Pasture renovation by oversowing. Proceedings of the New Zealand Grassland Association 47: 159-164. 